Analitika: Jurnal Magister Psikologi UMA, Vol. 11 (2) Desember (2019)

ISSN: 2085-6601 (Print), ISSN: 2502-4590 (Online)

DOI: http://dx.doi.org/analitika.v11i1.2878

ANALITIKA

Jurnal Magister Psikologi UMA

Available online http://ojs.uma.ac.id/index.php/analitika

\title{
Pengaruh Math Self-Efficacy dan Math Anxiety terhadap Performansi Matematika pada Siswa Kelas V SD
}

\section{Effects of Math Self-Efficacy and Math Anxiety towards Fifth Grader's Math Performance}

\author{
Tiffany Chandra *1) \& Lucia R. M. Royanto ${ }^{2)}$ \\ 1) Bidang Studi Psikologi Pendidikan, Program Studi Magister Psikologi Profesi, \\ Universitas Indonesia, Indonesia \\ 2) Program Studi Psikologi Pendidikan, Fakultas Psikologi, Universitas Indonesia, Indonesia
}

Diterima: 13 September 2019, disetujui: 28 Desember 2019, dipublish: 30 Desember 2019

*Corresponding author: E-mail: tiffany.chandra@ui.ac.id

\begin{abstract}
Abstrak
Hasil survei internasional menunjukkan bahwa performa Matematika siswa Indonesia, pada jenjang SD maupun SMP, tergolong rendah. Adapun upaya mengatasi hal tersebut sebaiknya dilakukan sejak jenjang SD, mempertimbangkan urgensi dari Matematika dalam kehidupan akademik maupun non-akademik. Beberapa penelitian menunjukkan bahwa faktor yang mempengaruhi performa Matematika siswa SD adalah math anxiety. Namun, peneliti berasumsi bahwa temuan tersebut tidak dapat digeneralisasikan pada siswa kelas IV-VI yang telah memasuki masa remaja. Pada masa tersebut, individu lebih mencemaskan kehidupan sosial daripada akademiknya. Dikatakan pula bahwa prestasi individu pada usia tersebut dipengaruhi oleh self-efficacy. Oleh karena itu, peneliti menguji antara math anxiety dan math self-efficacy, faktor mana yang lebih berpengaruh terhadap performa Matematika siswa kelas V SD, sehingga dapat menjadi dasar rancangan intervensi guna meningkatkan performa Matematika siswa. Partisipan terdiri dari 370 siswa/i kelas V di Jakarta Selatan. Data dikumpulkan melalui kuesioner dan diolah dengan pengujian multiple regression. Hasil penelitian menunjukkan bahwa math self-efficacy, daripada math anxiety, lebih berpengaruh terhadap performa Matematika siswa kelas V SD $\left(R^{2}=0,360, F(2,367)=103,052\right.$, $p<0,00)$. Dengan demikian, intervensi untuk meningkatkan performa Matematika siswa kelas VSD akan lebih efektif jika berfokus pada math self-efficacy.
\end{abstract}

Kata kunci: Performa matematika, efikasi diri matematika, kecemasan matematika, kelas V SD

\begin{abstract}
International surveys indicate that math performance of Indonesian students, at primary as well as secondary level are still low. This problem should be overcome at primary level, considering the urgency of mathematics in academic as well as non-academic settings. Researches indicate the factor which affect math performance at primary level is math anxiety. However, researchers of this study assume that those findings could not be generalized to 4-6 graders that is categorized as adolescent. During adolescence, individuals are more worried about social life than academics. Also, the achievement of adolescents was influenced by their self-efficacy. Therefore, this study aimed to test which factor between math anxiety and math self-efficacy has greater effect on the math performance of fifth grade students, so that it can be the basis of the interventions to improve students' math performance at that age. Participants consisted of 370 fifth graders in South Jakarta. Data collected through questionnaires and processed with multiple regression testing. Results showed that math self-efficacy has greater effects on math performance, rather than Mathematics anxiety, for fifth graders $\left(R^{2}=0,360, F\right.$ $(2,367)=103,052, p<0,00)$ Thus, interventions to improve the math performance of the fifth graders will be more effective if they focus on math self-efficacy.
\end{abstract}

Keywords: Math performance, math self-efficacy, math anxiety, fifth grade students

How to Cite: Chandra, Tifanny \& Lucia, R. M. R. (2019), Pengaruh Math Self-Efficacy dan Math Anxiety terhadap Performansi Matematika pada Siswa Kelas V SD, Analitika: Jurnal Magister Psikologi UMA, 11 (2): $126-136$ 
Tiffany Chandra \& Lucia R. M. Royanto, Pengaruh Math Self-Efficacy dan Math Anxiety terhadap

\section{PENDAHULUAN}

Indonesia menempati urutan 38 dari 42 negara yang mengikuti survei TIMSS (Trends in International Mathematics and Science Study) dalam hal kemampuan Matematika pada tahun 2011 (Mullis, Martin, Foy \& Arora, 2012). Pada survei berikutnya, tahun 2015, Indonesia menempati peringkat 44 dari 49 negara dengan skor 397 dari rata-rata skor internasional yang mencapai 500 (Mullis, Marin, Foy \& Hooper, 2016). Berdasarkan hasil survei PISA (Programme for International Students Assesment) tahun 2012, di lain sisi, Indonesia memperoleh rerata skor sebesar 375, yakni 119 poin di bawah rerata OECD dalam bidang Matematika (Organisations for Economic Co-operation and Development) (National Center for Education Statistics, 2012). Sementara, dalam survei PISA 2015, Indonesia memperoleh rerata Matematika sebesar 386, dengan rerata OECD pada tahun tersebut sebesar 490 (National Center for Education Statistics, 2019).

Adapun dalam penilaian PISA, ditentukan level 2, yakni rerata skor sebesar 420, 07 hingga kurang dari 482,38, sebagai level minimum (baseline level) kecakapan dalam Sains, Matematika dan membaca. Siswa yang memperoleh skor di bawah level 2 tersebut dikategorikan sebagai low performers (OECD, 2015). Level 2 menggambarkan kemampuan siswa sebagai berikut: mampu menginterpretasi dan menyadari situasi dalam berbagai konteks yang dapat disimpulkan secara langsung; mampu mengikhtisarkan informasi yang relevan dari suatu sumber tunggal dan memanfaatkan mode representasional tunggal; mampu menggunakan algoritma dasar, rumus, prosedur ataupun konvensi tertentu, serta mampu melakukan penalaran langsung dan membuat interpretasi harafiah mengenai hasil-hasil yang diperolehnya (OECD, 2009; 2013).

Survei PISA dilakukan terhadap siswa berusia 15 tahun, sementara TIMSS pada siswa kelas IV dan VIII. Dengan demikian, dapat dikatakan bahwa performa Matematika siswa Indonesia secara umum kurang menggembirakan, baik pada jenjang SD maupun SMP (Sekolah Menengah Pertama). Para siswa tersebut, khususnya siswa SMP, baru mencapai level 1 dalam standar kecakapan Matematika menurut PISA, yakni hanya mampu menjawab pertanyaanpertanyaan yang mengandung konteks familiar, yang menyajikan semua informasi relevan dan pertanyaannya didefinisikan dengan jelas; mampu mengidentifikasi informasi dan melakukan prosedur rutin sesuai instruksi langsung dalam konteks eksplisit; serta melakukan aksi nyata dan mengikuti stimuli yang diberikan dengan sesegera mungkin (OECD, 2009; 2013).

Kenyataan tersebut merupakan sesuatu yang patut dikhawatirkan karena Matematika merupakan salah satu pelajaran utama dalam sistem pendidikan di Indonesia yang dipelajari sejak jenjang Sekolah Dasar (SD). Nilai yang diperoleh dalam pelajaran Matematika berperan penting karena menentukan kelulusan seorang siswa dalam Ujian Nasional (Badan Pembinaan Hukum Nasional, 2005). Matematika juga berperan dalam situasi hidup sehari-hari, seperti saat berbelanja dan bekerja (Ding, 2016). Dalam masyarakat saat ini yang berbasis teknologi dan informasi, perkembangan dan keahlian Matematika pada anak-anak berusia muda juga dinyatakan sebagai prediktor penting dalam menentukan keberhasilan mereka di dunia kerja kelak, karena kemampuan tersebut diperlukan dalam berbagai tugas profesional dan berbagai pekerjaan menuntut 
kecakapan Matematika yang semakin tinggi dibandingkan sebelumnya (Nguyen, Watts, Duncan, Clements, Sarama, Wolfe, \& Spitler, 2016).

Para ahli di Amerika Serikat bahkan berusaha meningkatkan kemampuan Matematika para siswanya sejak usia prasekolah karena hal tersebut mempengaruhi prestasi Matematika mereka sepanjang masa mereka bersekolah (Clements \& Sarama, 2009). Clements dan Sarama (2009) juga mengatakan bahwa pengetahuan awal para siswa tersebut dalam Matematika juga menjadi prediktor penentu pencapaian mereka di kemudian hari dalam hal membaca. Selain itu, Matematika juga dinyatakan sebagai ilmu dasar yang harus dikuasai karena berperan dalam mengembangkan cara berpikir logis, bersikap kritis, dan bertindak rasional (Fauzi, 2009).

Terlepas dari pentingnya peran Matematika dalam pembentukan alur berpikir, pembentukan sikap, juga dalam pengaplikasiannya (Tanujaya, Prahmana, \& Mumu, 2017), ternyata Matematika masih menjadi mata pelajaran yang dianggap sulit oleh kebanyakan siswa di Indonesia (Disai, Dariyo, \& Basaria, 2017; Siregar, 2017). Bagi siswa Indonesia, Matematika merupakan hal menakutkan yang tidak jarang membuat mereka mendapatkan nilai buruk dalam mata pelajaran tersebut (Gewati, 2018).

Terkait kondisi performa Matematika siswa Indonesia, tentu diperlukan solusi untuk meningkatkan performa Matematika siswa Indonesia dengan mula-mula mencari tahu faktor-faktor yang mempengaruhi performa Matematika tersebut. Adapun penelitian-penelitian yang telah dilakukan lebih banyak mencari tahu faktor-faktor yang memengaruhi performa Matematika siswa SMP ataupun tingkat yang lebih tinggi.
Misalnya, Thien, Darmawan dan Ong (2015) dalam kajian mereka terhadap hasil PISA 2012 menemukan bahwa faktor yang paling berpengaruh terahadap performa Matematika peserta PISA dari Indonesia adalah efikasi diri Matematika (math selfefficacy). Padahal, hasil TIMSS yang buruk menunjukkan bahwa performa Matematika siswa SD juga belum maksimal. Oleh karena itu, penting untuk dicaritahu faktor apa yang paling berpengaruh terhadap performa Matematika siswa SD, sehingga dapat dirancang intervensi yang efektif dalam meningkatkan performa Matematika para siswa tersebut.

Berbagai penelitian terhadap siswa SD di Indonesia menunjukkan bahwa faktor yang paling sering dirujuk sebagai faktor yang mempengaruhi performa Matematika siswa SD adalah kecemasan Matematika (math anxiety), misalnya dalam penelitian Sintawati (2016) terhadap peserta TIMSS 2003-2011 (Kelas IV SD), Siregar (2017) pada siswa kelas V, Suci dan Purnomo (2016) pada siswa kelas V, ataupun Syafri (2017). Syafri (2017) juga menyatakan bahwa math anxiety berpengaruh negatif terhadap peforma Matematika siswa.

Adapun math anxiety didefinisikan sebagai perasaan tegang, cemas, atau takut yang dialami ketika berhadapan dengan tugas Matematika (Ashcraft, 2002). Legg dan Locker (2009) mengungkapkan hal yang kurang lebih senada, yakni math anxiety merupakan ketakutan ataupun ketegangan yang berkaitan dengan kegiatan berpikir/terlibat dalam tugas yang membutuhkan perhitungan atau interpretasi matematis. Ramirez, Shaw \& Maloney (2018) menyatakan bahwa math anxiety merupakan penghalang utama bagi individu untuk merarih kesuksesan dalam performa 
Matematika. Menurut mereka, ketakutan yang mendalam akan Matematika membuat siswa tidak mampu memandang tugas Matematika sebagai sesuatu yang masuk akal dan bermanfaat, sehingga mereka tidak berhasil dalam Matematika.

Jika benar bahwa math anxiety merupakan faktor yang paling mempengaruhi performa Matematika siswa SD, maka berbagai saran ataupun intervensi yang dikembangkan untuk mengatasi math anxiety, misalnya yang tercantum dalam penelitian Siregar (2017) mengenai pembelajaran Matematika melalui cara bermain game, akan efektif untuk meningkatkan performa Matematika siswa SD. Kendati demikian, peneliti berasumsi bahwa math anxiety sebagai faktor utama yang mempengaruhi performa Matematika tersebut tidak dapat digeneralisasi pada seluruh siswa SD dalam semua tingkatan. Jika dikaitkan dengan teori Psikososial Erikson, siswa-siswi yang berada pada masa akhir sekolah dasarnya, yakni siswa kelas IV-VI yang berusia sekitar 10-12 tahun, mulai memasuki usia remaja (adolescence). Pada tahap remaja ini, individu mengeksplorasi mengenai siapa diri mereka sebenarnya dan apa yang hendak mereka lakukan dalam hidup (Santrock, 2011). Dalam masa yang dikenal sebagai periode terjadinya identity versus identity confusion tersebut, para remaja mencoba berbagai peran dalam berbagai kegiatan (role experimentation) untuk menemukan hal-hal yang benar-benar menggambarkan diri mereka, termasuk mengeksplorasi berbagai hobi. Pada masa pencarian jati diri tersebut, hal yang penting bagi individu adalah relasi sosial dengan teman-teman sepantarannya. Mereka mengalami peer pressure yang ditandai dengan lebih seringnya mereka menyesuaikan diri dengan kegiatan ataupun cara pandang teman-teman seusianya (Santrock, 2013). Berlandaskan hal ini, peneliti berasumsi bahwa pada siswa kelas IV-VI SD, math anxiety tidak menjadi faktor yang paling berpengaruh terhadap performa Matematika mereka, karena kecemasan siswa pada usia tersebut seharusnya lebih dititikberatkan pada ranah relasi sosial.

Prestasi pada masa remaja secara umum dipengaruhi oleh baik faktor-faktor intrinsik maupun ekstrinsik, dengan salah satu proses kognitif yang menjadi faktor penentu prestasi mereka adalah efikasi diri (self-efficacy). Dikatakan bahwa remaja dengan self-efficacy tinggi menunjukkan kemajuan pada sejumlah aspek prestasi (Santrock, 2013).

Dalam kaitannya dengan Matematika, math self-efficacy, yakni penilaian seseorang terhadap kemampuannya sendiri, baik dalam dalam memecahkan soal Matematika tertentu, mengerjakan tugas yang berkaitan dengan Matematika, ataupun berhasil dalam bidang-bidang yang berhubungan dengan Matematika (Pajares \& Miller, 1994), juga banyak diteliti sebagai faktor yang paling berpengaruh terhadap performa Matematika seseorang. Misalnya, Stevens, Olivarez, Lan \& Tallent-Runnels (2010) menemukan bahwa math self-efficacy memprediksi performansi Matematika maupun variabel-variabel motivasional lain yang mempengaruhi pencapaian Matematika secara keseluruhan. Siswa dengan math self-efficacy yang tinggi cenderung akan mencari tugas-tugas Matematika menantang lainnya, juga subjeksubjek yang berkaitan dengan Matematika. Sebaliknya, siswa dengan math self-efficacy rendah biasanya mengikuti pelajaran Matematika dan mencari tugas-tugas yang berkaitan dengan Matematika hanya ketika hal tersebut diharuskan ataupun mereka 
ditekan oleh orangtua. Collins (1982 dalam Pajares \& Miller, 1994) menemukan pula bahwa anak dengan self-efficacy tinggi akan lebih unggul dalam memecahkan permasalahan Matematika yang baru dibandingkan anak dengan self-efficacy rendah, ketika dilakukan pengendalian terhadap performa terdahulu (prior performance). Selain itu, anak dengan selfefficacy lebih tinggi takan menunjukkan usaha yang lebih keras, misalnya dengan bertahan lebih lama dalam mengerjakan kembali soalsoal yang dijawab dengan keliru.

Bandura (1993) juga menjelaskan bahwa individu cenderung lebih menentukan aksi mereka dalam situasi mengancam berdasarkan efikasi terhadap kemampuannya dalam melakukan coping daripada berdasarkan munculnya kecemasan. Bandura (1986 dalam Pajares \& Miller, 1994) menjelaskan bahwa anxiety ditentukan oleh kepercayaan diri individu terkait suatu tugas, sementara efficacy beliefs memprediksi seberapa baik individu dapat mengatasi suatu keadaan mengancam serta seberapa besar rasa takut yang akan muncul. Bandura mengungkapkan bahwa self-efficacy akan tetap mempertahankan suatu prediksi terhadap performansi, sekalipun efek dari kecemasan telah dikontrol, tetapi efek kecemasan akan menghilang jika dilakukan pengontrolan terhadap self-efficacy. Kendati demikian, menurut Bandura (1993), dalam menghadapi tuntutan akademik, siswa yang memiliki efikasi rendah rentan mengalami kecemasan terkait prestasinya.

Berdasarkan penjelasan di atas, peneliti berasumsi bahwa math self-efficacy akan lebih besar pengaruhnya terhadap performa Matematika pada siswa SD, khususnya siswa kelas IV-VI, daripada math anxiety. Adapun jika asumsi tersebut terbukti, hasil penelitian ini akan berguna sebagai dasar untuk merancang intervensi yang lebih terfokus pada faktor yang lebih besar pengaruhnya terhadap performa Matematika pada siswa di masa akhir SD tersebut. Dengan demikian, dapat dilakukan tindakan untuk mengatasi masalah rendahnya performa Matematika pada siswa SD di Indonesia yang tidak teratasi oleh berbagai intervensi dengan fokus math anxiety, yang mungkin lebih sesuai untuk siswa kelas I-III.

Intervensi yang lebih terfokus pada faktor yang lebih berpengaruh terhadap performa Matematika siswa tersebut juga penting dilakukan karena para siswa di akhir masa SD harus dipersiapkan untuk berhasil dalam Ujian Nasional, yang mana salah satu mata pelajarannya adalah Matematika. Selain itu, intervensi tersebut tentu dapat digunakan pula bagi siswa di jenjang pendidikan yang lebih tinggi, yakni SMP dan SMA, karena mereka masih berada di tahap perkembangan yang sama, yakni remaja (Santrock, 2011).

Rumusan masalah penelitian ini disusun sebagai berikut: Apakah math selfefficacy lebih berpengaruh secara signifikan terhadap performa Matematika pada siswa kelas V SD daripada math anxiety? Sementara itu, hipotesis penelitian yang diajukan adalah: Hipotesis 1: Math self-efficacy lebih berpengaruh secara signifikan terhadap performa Matematika pada siswa kelas V SD daripada math anxiety.

Adapun dalam penelitian ini, kriteria partisipan adalah siswa kelas V SD yang berusia sekitar 10-11 tahun. Pada usia tersebut, secara perkembangan kognitif, mereka telah memasuki tahap operasional formal, sehingga mampu berpikir abstrak, idealistik, dan logis (Santrock, 2011). Dengan demikian, diharapkan para partisipan tersebut dapat sungguh-sungguh melakukan 
proses pemecahan masalah secara logis dalam mengerjakan persoalan Matematika. Selain itu, pada usia 8-11 tahun, individu juga telah mengembangkan math-anxiety (ZirkSadowski, Lamptey, Devine, Haggard \& Szűcs, 2014). Dengan demikian, pada usia kelas $V$ SD, para partisipan telah dapat diukur tingkat math-anxiety-nya.

\section{METODE PENELITIAN}

Pengambilan data dalam penelitian ini dilakukan secara kuantitatif dengan cara mendistribusikan kuesioner penelitian kepada partisipan di 13 kelas di 5 SD wilayah Jakarta Selatan. Kelima SD tersebut terdiri dari 2 sekolah swasta, 2 sekolah negeri dan 1 MIN (Madrasah Ibtidaiyah Negeri). Adapun penelitian ini dinyatakan lolos dalam pengkajian etika penelitian (research ethics approval) oleh pihak Komite Etik Penelitian Fakultas Psikologi Universitas Indonesia dengan surat keterangan bernomor 604/FPsi.Komite Etik/PDP.04.00/2019.

Partisipan penelitian terdiri dari 370 siswa/i yang diperoleh menggunakan teknik convenience sampling. Para partisipan tersebut terdiri dari 164 laki-laki dan 206 perempuan. Rerata usia partisipan adalah 10 tahun $(M=10,27 ; S D=0,6)$. Setiap proses pengambilan data telah melalui perizinan dari masing-masing sekolah dengan surat permohonan izin resmi yang diterbitkan oleh Fakultas Psikologi Universitas Indonesia. Selain itu, setiap partisipan yang ikut serta juga telah diberi izin oleh orangtuanya melalui proses penandatangan Informed Consent.

Performa Matematika diukur menggunakan Tes Prestasi Matematika (Math Achievement Test) yang dikembangkan oleh peneliti. Tes Prestasi Matematika ini terdiri dari 12 aitem berbentuk esai dengan soal-soal yang diambil dari materi kelas IV semester II dan kelas V semester I. Adapun setiap aitem telah melalui proses konfirmasi dengan beberapa guru Matematika SD untuk memastikan bahwa materi yang digunakan telah dipelajari oleh partisipan. Dalam setiap aitem, setiap jawaban salah akan diberi nilai 0 dan jawaban benar diberi nilai 1 . Adapun nilai reliabilitas dari alat ukur tersebut sebesar $\alpha=0,71$. Sementara itu, item difficulties alat ukur ini adalah antara 0,040,69 dengan rerata sebesar 0,34 . Soal dibuat dengan tingkat kesulitan rendah hingga tinggi sebagai upaya penyesuaian dengan kemampuan partisipan yang berasal dari berbagai sekolah berbeda. Ketidaksesuaian antara kemampuan Matematika partisipan dengan tingkat kesulitan soal akan menyebabkan alat ukur sulit mencapai tingkat reliabilitas yang diharapkan (Mullis, Martin, Foy \& Arora, 2012). Adapun item discrimination alat ukur ini memiliki rentang 0,10-0,77 dengan rerata sebesar 0,51.

Math self-efficacy diukur menggunakan Skala Efikasi Diri yang dikembangkan oleh peneliti. Adapun alat ukur tersebut terdiri dari 12 aitem yang disandingkan dengan setiap aitem math performance dengan kalimat pertanyaan, "Seberapa yakin kamu dalam mengerjakan soal ini?". Alat ukur Efikasi Diri tersebut menggunakan 4 poin skala Likert (1=Sangat Tidak Yakin, 4=Sangat Yakin). Semakin tinggi skor math self-efficacy yang diperoleh menunjukkan semakin tingginya keyakinan diri partisipan terhadap kemampuannya sendiri dalam mengerjakan setiap aitem math performance sandingan. Adapun nilai reliabilitas dari alat ukur ini adalah $\alpha=0,84$.

Math anxiety diukur menggunakan modified Abbreviated Math Anxiety Scale 
(mAMAS) yang disesuaikan oleh ZirkSadowski, Lamptey, Devine, Haggard \& Szűcs (2014) untuk partisipan kelas 5 SD di Inggris dari alat ukur aslinya Abbreviated Math Anxiety Scale (AMAS) yang dikembangkan oleh Hopko, Mahadeva, Bare \& Hunt (2003). Adapun mAMAS tersebut diterjemahkan melalui proses translate and back translate dan telah mendapatkan expert judgement oleh ahli bidang Psikologi Pendidikan setelah memperoleh izin dari Szűcs maupun Zirk-Sadowski melalui korespondensi surat elektronik. Selain itu, dilakukan pula adaptasi dengan mengubah bentuk pilihan jawaban yang semula terdiri dari skala Likert 5 poin (1=Kecemasan Rendah; $5=$ Kecemasan Tinggi) menjadi bentuk $\Leftrightarrow$,

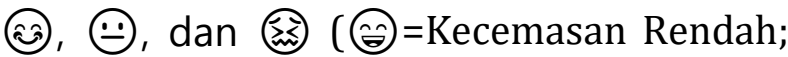
(2)=Kecemasan Tinggi). Saat dilakukan pengujian pada alat ukur yang terdiri dari 9 aitem ini, didapatkan nilai reliabilitas sebesar $\alpha=0,74$.

Adapun data yang diperoleh diolah menggunakan analisis regresi berganda (multiple regression) untuk melihat pengaruh self-efficacy dan math anxiety secara bersama-sama terhadap performa Matematika.

\section{HASIL DAN PEMBAHASAN}

Pada bagian hasil akan dipaparkan perolehan partisipan pada masing-masing alat ukur, kemudian dilanjutkan dengan pemaparan hasil pengujian korelasi sebagai prasyarat dari pengujian multiple regression. Setelah itu, akan dipaparkan hasil multiple regression untuk menjawab pertanyaan penelitian.
Tabel 1. Statistik deskriptif

\begin{tabular}{lcccc}
\hline & Min & Max & Mean & Std. \\
\hline achievement & 0,00 & 1,00 & 0,34 & 0,21 \\
efficacy & 1,00 & 4,00 & 2,44 & 0,61 \\
anxiety & 1,00 & 4,00 & 2,24 & 0,55 \\
\hline
\end{tabular}

Tabel 1. menunjukkan bahwa baik performa Matematika, math self-efficacy, maupun math anxiety partisipan cenderung rendah. Rerata math anxiety yang cenderung rendah tersebut relevan dengan penjelasan pada bagian pendahuluan bahwa para siswa di akhir masa SD, dalam hal ini siswa kelas V SD, yang telah memasuki masa remaja, kemungkinan akan kurang mencemaskan halhal yang berkaitan dengan prestasi akademik, karena yang penting bagi mereka pada usia tersebut adalah relasi sosial.

Tabel 2. Koefisien korelasi math self-efficacy, math anxiety dengan performa matematika

\begin{tabular}{lccc}
\hline & mean_ach & mean_eff & mean_anx \\
\hline mean_ach & - & & \\
mean_eff & $0,599^{* *}$ & - \\
& $(\mathrm{p}=0,000)$ & \\
mean_anx & $-0,237^{* *}$ & $-0,366^{* *}$ & - \\
& $(\mathrm{p}=0,000)$ & $(\mathrm{p}=0,000)$ \\
**Correlation is significantat $p<0,01(2$-tailed $)$
\end{tabular}

Hasil uji korelasi menunjukkan relevansi dengan penelitian McMullan, Jones dan Lea (2012), bahwa semakin math self-efficacy seseorang meningkat, math anxiety akan semakin rendah, dan sebaliknya. Pada Tabel 2 , tampak keduanya berhubungan secara negatif dan signifikan $(r(269)=-0,366$, $p<0,01$ ). Tabel 2. menunjukkan pula bahwa prasyarat untuk melakukan multiple regression terpenuhi, yakni terdapat hubungan yang signifikan antara math anxiety dan performa Matematika $(r(269)=$ $-0,237, p<0,01)$, serta terdapat hubungan signifikan antara math self-efficacy dan 
performa Matematika $(r(269)=0,599$, $p<0,01)$.

Tabel 3. Hasil uji multiple regression math selfefficacy dan math anxiety terhadap performa matematika

\begin{tabular}{|c|c|c|c|c|c|c|c|c|}
\hline \multirow[b]{2}{*}{ Var } & \multirow[b]{2}{*}{$R$} & \multirow[b]{2}{*}{$\begin{array}{c}\text { Adjust- } \\
\text { ed } R \\
\text { Square }\end{array}$} & \multirow[b]{2}{*}{$F$} & \multirow[b]{2}{*}{$\begin{array}{l}\text { Sig } \\
. F\end{array}$} & \multicolumn{2}{|c|}{$\begin{array}{c}\text { Unstan- } \\
\text { dardized } \\
\text { Coeff. }\end{array}$} & \multicolumn{2}{|c|}{ Std. Coeff. } \\
\hline & & & & & $b$ & $\begin{array}{l}\text { Std. } \\
\text { Err. }\end{array}$ & $B$ & Sig \\
\hline & 0,6 & 0,356 & 103, & 0,0 & & & & \\
\hline & 00 & & 052 & 00 & & & & \\
\hline Cons- & & & & & $-0,1$ & 0,0 & & 0,0 \\
\hline tant & & & & & 40 & 64 & & 30 \\
\hline mean & & & & & 0,2 & 0,0 & 0,5 & 0,0 \\
\hline _eff & & & & & 05 & 16 & 92 & 00 \\
\hline mean & & & & & $-0,0$ & 0,0 & $-0,0$ & 0,6 \\
\hline _anx & & & & & 08 & 17 & 20 & 48 \\
\hline
\end{tabular}

Adapun ketika dilakukan uji multiple regression (Tabel 3), didapatkan bahwa math self-efficacy dan math anxiety secara bersamasama tidak memiliki pengaruh yang signifikan terhadap performa Matematika pada siswa kelas V SD. Dengan demikian, model regresi ini tidak dapat digunakan untuk memprediksi performa Matematika. Meskipun begitu, proporsi varians dari performa Matematika yang dijelaskan oleh math self-efficacy dan math anxiety cukup besar, yakni 36\%, sedangkan 64\% sisanya dipengaruhi oleh variabel-variabel lain di luar penelitian ini $\left(R^{2}=0,360, F(2,367)=\right.$ $103,052, p<0,00)$.

Hasil pada Tabel 3. juga menunjukkan bahwa performa Matematika siswa meningkat 0,205 poin pada setiap kenaikan 1 poin math self-efficacy dan menurun 0,008 poin setiap kenaikan 1 poin math anxiety. Dengan demikian, hipotesis penelitian ini terbukti, yakni bahwa math self-efficacy lebih berpengaruh secara signifikan terhadap performa Matematika pada siswa kelas V SD daripada math anxiety.

Seperti yang telah dijelaskan sebagai dasar argumentasi pada bagian pendahuluan, fenomena ini terjadi karena pada masa-masa memasuki remaja awal ini, para partisipan lebih berfokus untuk mengeksplorasi berbagai peran dalam aneka kegiatan untuk membangun jati dirinya, serta lebih mementingkan relasi sosialnya, terutama dengan teman-teman sepantarannya. Lebih jauh lagi, dijelaskan dalam Santrock (2013) bahwa kepentingan sosial remaja dapat menjadi penentu prestasi mereka. Dikatakan bahwa biasanya, prestasi remaja tidak mencerminkan kemampuan mereka yang sebenarnya. Peer pressure dapat saja membuat remaja bertingkah laku mengikuti norma yang berlaku dalam kelompok sosialnya, sehingga remaja yang sebenarnya memiliki kemampuan intelektual yang tinggi mungkin saja menunjukkan pola pencapaian prestasi yang maladaptif, hingga berakhir sebagai low achievers (Santrock, 2013).

Performa akademik remaja juga dipengaruhi kehidupan sosial di luar pertemanannnya. Ekspektasi orangtua ataupun guru terhadap prestasi remaja dikatakan akan mempengaruhi pula motivasi dan self-efficacy mereka dalam berprestasi (Santrock, 2013). Hal ini berkaitan pula dengan masa eksplorasi identitas ataupun jati diri mereka. Ketika performa akademik yang baik dapat menjadi bagian dari jati diri remaja, maka prestasi tersebut akan diperjuangkan untuk dicapai (Santrock, 2011; 2013), sehingga remaja tersebut akan memperoleh pengakuan sosial pula.

Adapun pada bagian ini, akan didiskusikan pula hasil penelitian yang telah diperoleh. Hasil penelitian ini memunculkan asumsi bahwa beberapa hasil penelitian terdahulu pada siswa kelas V SD, bahwa math anxiety mempengaruhi performa Matematika (Siregar, 2017; Suci \& Purnomo, 
2016; Syafri, 2017), dapat terjadi karena pada partisipan dalam penelitian-penelitian tersebut sesungguhnya memiliki math selfefficacy yang berbanding terbalik dengan math anxiety yang diukur saat itu, sehingga sebenarnya math self-efficacy para partisipan tersebutlah yang lebih berpengaruh terhadap performa Matematikanya. Jika dilakukan pengukuran dan pengontrolan terhadap math selfefficacy pada penelitian-penelitian tersebut, seyogianya hubungan math anxiety dan performa Matematika tersebut akan melemah, seperti yang dipaparkan dalam teori Bandura (1986 dalam Pajares \& Miller, 1994) di atas.

Oleh karena itu, alih-alih membuat rancangan intervensi untuk mengatasi math anxiety seperti yang dipaparkan dalam penelitian Siregar (2017), intervensi yang berfokus meningkatkan math self-efficacy akan lebih efektif untuk memperbaiki performa Matematika pada siswa SD, khususnya yang duduk di kelas V.

Adapun salah satu bentuk upaya yang telah terbukti berhasil meningkatkan math self-efficacy siswa misalnya penerapan Program Based Learning yang dilakukan terhadap siswa kelas VIII SMP di Yogyakarta (Masitoh \& Fitriyani, 2018). Selain itu, terdapat pula penelitian Psycharis dan Kallia (2017) yang membuktikan bahwa computer programming dapat meningkatkan kemampuan penalaran (reasoning skill) dan math self-efficacy siswa berusia 16 - 17 tahun. Kendati demikian, intervensi untuk meningkatkan math self-efficacy pada siswa SD, khususnya kelas $\mathrm{V}$, masih belum ditemukan. Mempertimbangkan kembali pentingnya intervensi-intervensi semacam itu untuk dilakukan, disarankan agar penelitian-penelitian selanjutnya berfokus pada pengembangan upaya-upaya untuk meningkatkan math self-efficacy pada siswa SD tersebut. Guna melakukan hal tersebut, perlu pula dilakukan studi yang lebih mendalam mengenai dinamika terjadinya math self-efficacy yang rendah, khususnya pada siswa kelas V SD.

Selain itu, meskipun asumsi penelitian ini didasari oleh teori bahwa para siswa di masa akhir SD yang telah memasuki masa remaja, yakni kelas IV hingga kelas V, akan memiliki kecemasan yang lebih dititikberatkan pada persoalan relasi sosial dan bukan prestasi akademik, hasil penelitian ini belum dapat digeneralisasi kepada populasi siswa kelas IV ataupun VI karena tidak ada sampel partisipan dari kedua jenjang tersebut. Hasil ini terutama tidak dapat digeneralisasikan pada populasi siswa kelas IV SD yang berada pada peralihan anak usia sekolah (school-age) menjadi remaja (adolescence). Hal ini terjadi karena pada masa tersebut, mereka akan mengalami psychosocial moratorium, yakni masa terjadinya perubahan dari keamanan masa kanak-kanak (childhood security) menjadi otonomi masa dewasa (adult autonomy) (Santrock, 2011). Oleh karena itu, penelitian-penelitian selanjutnya diharapkan dapat melihat dinamika ketiga variabel tersebut, yakni math self-efficacy, math anxiety, dan performa Matematika, secara lebih mendalam, terutama pada usiausia yang belum tercakup dalam penelitian ini, ataupun pada populasi-populasi siswa dengan karakteristik lainnya.

\section{SIMPULAN}

Hasil penelitian ini menunjukkan bahwa dibandingkan dengan math anxiety, math self-efficacy ternyata lebih berpengaruh terhadap performa 
Matematika pada siswa kelas V SD. Pada jenjang kelas $\mathrm{V}$ tersebut, secara teoritis kecemasan para siswa bukan terletak pada performa atau prestasi akademik mereka, tetapi lebih terletak pada relasi sosial. Di sisi lain, math self-efficacy ternyata dapat meningkatkan upaya dalam mencapai nilai yang baik dalam Matematika. Oleh karena itu, untuk meningkatkan performa Matematika siswa pada kelas $\mathrm{V}$, sebaiknya dirancang berbagai intervensi yang lebih berfokus pada peningkatan math selfefficacy para siswa, bukan pada upaya menurunkan math anxiety mereka.

\section{DAFTAR PUSTAKA}

Ashcraft, M. H. (2002). Math Anxiety: Personal, Educational, and Cognitive Consequences. Current Directions in Psychological Science, 11(5): $181-185$.

Badan Pembinaan Hukum Nasional. (2005). Peraturan Pemerintah Republik Indonesia tentang Standar Nasional Pendidikan, No. 19. Jakarta: Pengarang.

Bandura, A. (1993). Perceived Self-Efficacy in Cognitive Development and Functioning. Educational Psychologist, 28(2): 117-148.

Clements, D. H. \& Sarama, J. (2009). Learning and Teaching Early Math: The Learning Trajectories Approach. New York: Routledge.

Ding, Y. (2016). How Do Students' Mathematics SelfEfficacy, Mathematics Self-Concept and Mathematics Anxiety Influence Mathematical Literacy?: A Comparison between ShanghaiChina and Sweden in PISA 2012. PostGraduate Thesis. Gothenburg, Sweden: University of Gothenburg.

Disai, W. I., Dariyo, A. \& Basaria, D. (2017). Hubungan antara Kecemasan Matematika dan Self-Efficacy dengan Hasil Belajar Matematika Siswa SMA X Kota Palangkaraya. Jurnal Muara Ilmu Sosial, Humaniora dan Seni, 1(2): 556-568.

Fauzi, K. M. A. (2009). Peranan Kemampuan Metakognitif dalam Pemecahan Masalah Matematika Sekolah Dasar. Jurnal Kultura, 11(1): 1162-1116.

Gewati, M. (2018). Kemampuan Matematika Siswa Indonesia Memprihatinkan, Solusinya? Diunduh dari https://edukasi,kompas.com pada 2 Agustus 2019.
Hopko, D. R., Mahadevan, R., Bare, R. L. \& Hunt, M. K. (2003). The Abbreviated Math Anxiety Scale (AMAS): Construction, Validity, and Reliability. Assessment, 2003(10): 178-182.

Legg, A. M. \& Locker, Jr. L. (2009). Math Performance and Its Relationship to Math Anxiety and Metacognition. North American Journal of Psychology, 11(3): 471-486.

Masitoh, L. F. \& Fitriyani, H. (2018). Improving Students' Mathematics Self-Efficacy Through Problem Based Learning. Malikussaleh Journal of Mathematics Learning, 1(1): 26-30.

McMullan, M., Jones, R. \& Lea, S. (2012). Math Anxiety, Self-Efficacy, and Ability in British Undergraduate Nursing Student. Research in Nursing E Health, 2012(35): 178-186.

Mullis, I. V. S., Martin, M. O., Foy, P. \& Arora, A. (2012). TIMSS 2011 International Results in Mathematics. USA: TIMSS \& PIRLS International Study Center.

Mullis, I. V. S., Martin, M. O., Foy, P. \& Hooper, M. (2016). TIMSS 2015 International Results in Mathematics. USA: TIMSS \& PIRLS International Study Center.

National Center for Education Statistics. (2012). Mathematics Literacy: Average Scores. Diunduh di https://nces.ed.gov/surveys/pisa/pisa2012/pis a2012 highlights_3a.asp tanggal 1 Agustus 2019.

National Center for Education Statistics. (2015). Mathematics Literacy: Average Scores. Diunduh di https://nces.ed.gov/surveys/pisa/pisa2015/pis a2015highlights_5.asp tanggal 1 Agustus 2019.

Nguyen, T., Watts, T. W., Duncan, G. J., Clements, D. H., Sarama, J. S., Wolfe, C. \& Spitler, M. E. (2016). Which Preschool Mathematics Competencies are Most Predictive of Fifth Grade Achievement?. Early Childhood Research Quarterly, 36(2016): 550-560.

OECD. (2009). PISA 2009 Assesment Framework: Key Competencies in Reading, Mathematics and Science. Diunduh di http://www.oecd.org/pisa/pisaproducts/4445 5820.pdf tanggal 9 Agustus 2019.

OECD. (2013). PISA 2012 Assesment and Analytical Framework: Mathematics, Reading, Science, Problem Solving and Financial Literacy. OECD Publishing.

OECD. (2015). Definitions PISA (2015). Diunduh di http://gpseducation.oecd.org/Content/Notes /Definitions_PISA_GPS.pdf tanggal 20 Juli 2019.

Pajares, F. \& Miller, M. D. (1994), Role of Self-Efficacy and Self-Concept Beliefs in Mathematical 
Problem Solving: A Path Analysis. Journal of Educational Psychology, 86(2): 193-203.

Psycharis, S. \& Kallia, M. (2017). The Effects of Computer Programming on High School Students' Reasoning Skills and Mathematical Self-Efficacy and Problem Solving. Instr Sci, 2017(45): 583-602.

Ramirez. G., Shaw, S. T. \& Maloney, E. A. (2018). Math Anxiety: Past Research, Promising Interventions, and A New Interpretation Framework. Educational Psychologist, 53(3): 145-164.

Santrock, J. W. (2011). Child Development: An Introduction, $13^{\text {th }}$ ed. New York: McGraw Hill.

Santrock, J. W. (2013). Adolescence, $15^{\text {th }}$ ed. New York: McGraw Hill.

Sintawati, M. (2016). Helping Students with Mathematics Anxiety. International Conference on Education, Technology, and Sciences: Integrating Technology and Science into Early Childhood and Primary Education. Jambi 2-3 November 2016.

Siregar, N. R. (2017). Persepsi Siswa pada Pelajaran Matematika: Studi Pendahuluan pada Siswa yang Menyenangi Game. Prosiding Temu Ilmiah X Ikatan Psikologi Perkembangan Indonesia. Semarang 22-24 Agustus 2017.

Stevens, T., Olivarez, A., Lan, W. Y. \& TallentRunnels, M. K. (2010). Role of Mathematics Self-Efficacy and Motivation in Mathematics Performances Across Ethnicity. The Journal of Educational Research, 97(4): 208-222.

Suci, V. W. \& Purnomo, Y. W. (2016). Hubungan antara Konsepsi Penilaian dan Kecemasan Siswa Sekolah Dasar di Kelas Matematika. Jurnal Tadris Matematika, 9(1): 48-6o.

Syafri, F. S. (2017). Ada Apa dengan Kecemasan Matematika. Journal of Mathematics Education, 1(2017): 59-65.

Tanujaya, B., Prahmana, R. C. I. \& Mumu, J. (2017). Mathematics Instruction, Problems, Challenges and Opportunities: A Case Study in Manokwari Regency, Indonesia. World Transactions on Engineering and Technology Education, 15(3): 287-291.

Thien, L. M., Darmawan, I. G. N. \& Ong, M. Y. (2015). Affective Characteristics and Mathematics Performance in Indonesia, Malaysia, and Thailand: What Can PISA 2012 Data Tell Us?. Large-Scale Assesments in Education, 2015(3): 2-16.

Zirk-Sadowski, J., Lamptey, C., Devine, A., Haggard, M. \& Szücs, D. (2014). Young-Age Gender Differences in Mathematics Mediated by
Independent Control or Uncontrollability. Developmental Sciences, 2014: 1-10. 